\title{
Unusual host plant of Hoplitis pici, a bee with hooked bristles on its mouthparts (Hymenoptera: Megachilidae: Osmiini)
}

\author{
ANDREAS MÜLLER \\ Institute of Plant Sciences, Applied Entomology, ETH Zürich, Schmelzbergstrasse 9 / LFO, CH-8092 Zürich, Switzerland; \\ e-mail: andreas.mueller@ipw.agrl.ethz.ch
}

Key words. Osmiine bees, Hoplitis, oligolectic, pollen-harvesting device, Muscari, Hyacinthaceae

\begin{abstract}
Hoplitis pici (Friese, 1899) is a rare species of bee occurring in southeast Europe, Turkey and the Near East. The females are equipped with conspicuous hooked bristles on the galeae of the proboscis. Microscopical analysis of both pollen contained in the abdominal scopa and sticking to the bodies of females indicates a distinct preference of $\mathrm{H}$. pici for the flowers of Muscari Miller (Hyacinthaceae), which are characterized by having the anthers completely hidden within an urn-shaped corolla. Field observations showed that the specialized bristles serve to scrape pollen out of the Muscari flowers. Specialized bristles aiding female bees to extract pollen from narrow flower tubes must have independently evolved at least eight times in osmiine bees. $H$. pici is the only osmiine species known to use its pollen-harvesting bristles to exploit host plants other than narrow-tubed Boraginaceae.
\end{abstract}

\section{INTRODUCTION}

Though bees feed their larvae on pollen, morphological specializations especially developed for collecting pollen from flowers are rarely observed. Specialized pollen-harvesting devices are known to have evolved in bees exploiting (1) nototribic flowers where the raised position of the anthers renders an efficient collection of pollen difficult, (2) flowers of small size packed in dense inflorescences where the separate exploitation of each flower is inefficient and (3) flowers where the anthers are hidden within narrow tubes (Müller \& Bansac, 2004). Bees that collect pollen from flowers with concealed anthers are equipped with hooked or otherwise modified bristles on the proboscis or on the forelegs, which are used to scrape pollen out of narrow flower tubes. Such specialized bristles have repeatedly and independently evolved in many bee lineages within six out of the seven extant bee families as well as in several biogeographic regions (Thorp, 1979, 2000; Parker \& Tepedino, 1982; Müller, 1995; Müller \& Kuhlmann, 2003; Neff, 2004). Analogous morphological adaptations are also found in masarid wasps (Neff \& Simpson, 1985)

Hoplitis (Hoplitis) pici (Friese, 1899) is a rare bee known from southeast Europe, Turkey and the Near East (Zanden, 1988; Ungricht et al., in prep.). While the males of $\mathrm{H}$. pici can easily be identified by the peculiar shape of their antennae (Friese, 1899; Morice, 1901), the female is still unknown (Zanden, 1987). Revisional work on osmiine bees collected by W. Arens (Bad Hersfeld, Germany) in Greece has recently led to the detection of the female of $H$. pici (A. Müller, unpubl.). While the females of Hoplitis (Hoplitis) are in general very uniform and notoriously difficult to identify, those of $H$. pici are immediately recognizable by the conspicuous hooked bristles on the proboscis.

Here, we confirm the putative function of the hooked bristles in $H$. pici as a pollen-collecting device and report on the species' preference for an unusual host plant.

\section{MATERIAL AND METHODS}

To determine the plants from which $H$. pici collects pollen, the scopal pollen contents of females were analyzed by light microscopy using the method outlined by Westrich \& Schmidt
(1986). After removing pollen from the abdominal scopa, the pollen was embedded in glycerine gelatine on a slide. The percentages of different pollen types within a sample were estimated by counting the grains along four lines chosen randomly across the cover slip at a magnification of $400 \times$. To prevent biases caused by contamination, pollen types represented by less than $5 \%$ of the counted grains were not considered. The pollen grains were identified at a magnification of $400 \times$ or $1000 \times$ with the aid of the literature cited in Westrich \& Schmidt (1986) and a reference collection consisting of pollen samples of more than 500 plant species. Pollen grains were identified down to family, tribal or genus level. As $H$. pici is obviously rare and the hitherto unknown females are probably concealed in the undetermined material of entomological collections, only seven females were found with a reasonable amount of pollen in their abdominal scopae. These seven specimens were collected at five different localities in Greece and one in Turkey. To compensate for this limited number of samples, pollen grains adhering to head, mouthparts, legs, thorax or abdomen of ten additional females originating from six different localities in Greece and two different localities in Turkey were picked off with a fine needle. These pollen grains were mounted as described above and qualitatively analyzed.

The pollen-collecting behaviour of several females of $\mathrm{H}$. pici was observed in the field using a threefold magnifying lens. The field observations took place at Stegna on the island of Rhodos (Greece) in May 2005.

\section{RESULTS}

In $\mathrm{H}$. pici the specialized bristles are confined to the galeae of the proboscis (Fig. 1). They are stiff and strongly recurved apically (Fig. 2). Only females are equipped with such bristles. In the males, the proboscis is loosely beset with fine and short hairs of normal shape.

All seven scopal contents analysed consisted exclusively or predominantly of one pollen type belonging to lilioid monocotyledons (Table 1). At a magnification of $1000 \times$, this pollen type was found to exactly correspond to reference pollen samples of Muscari Miller (Hyacinthaceae). Two samples additionally contained a small amount of Asteraceae pollen. 


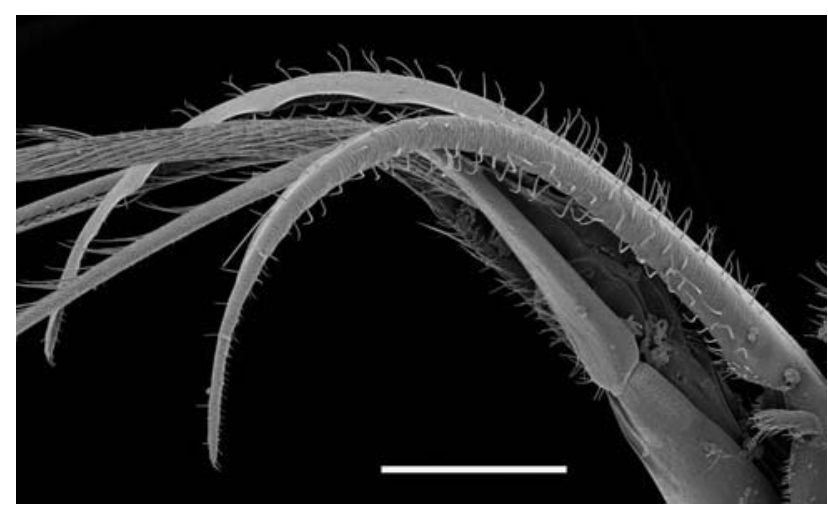

Fig. 1. Hoplitis pici: Proboscis with pollen-harvesting bristles on the galeae $($ scale bar $=600 \mu \mathrm{m})$.

The pollen adhering to the body of the ten females devoid of pollen in their scopa contained grains of Muscari in all but two cases. The other pollen grains were from Echium (Boraginaceae), Campanula (Campanulaceae), Lotus (Fabaceae), Lactuceae (Asteraceae), Brassicaceae and Lamiaceae, respectively.

Field observations showed that the females of $H$. pici indeed use Muscari as a host plant. At the observation site on Rhodos the females exploited the fertile flowers of Muscari comosum (L.) Miller (Fig. 3). Pollen-harvesting females inserted their extended proboscis into the small opening of the more or less horizontally oriented, urn-shaped, 5-9 $\mathrm{mm}$ long flowers and extracted pollen from the hidden anthers by rapidly moving the proboscis repeatedly back and forth.

\section{DISCUSSION}

In the palaearctic, narrow-tubed flowers exploited by bees with hooked bristles on their proboscis or forelegs belong to the Boraginaceae or the Primulaceae (Müller, 1995; Müller \& Kuhlmann, 2003) and as shown in the present study, the Hyacinthaceae. In Muscari, the six petals are connate forming an urn-shaped flower with a narrow opening and completely hide the anthers. Thus, Muscari flowers closely correspond morphologically to the narrow-tubed flowers of Boraginaceae and Primulaceae.

The nominate subgenus Hoplitis, which is geographically restricted to the palaearctic, comprises about 40 species (Michener, 2000; Ungricht et al., in prep.). All species of which the flower preferences are known exhibit strict floral specificity: pollen is collected either from Echium (Boraginaceae), which possesses open flowers with readily accessible anthers, or representatives of the Fabaceae (Ducke, 1900; Westrich, 1989; Le Goff, 2003, 2004; A. Müller, unpubl.). With its preference for Muscari, H. pici clearly differs from its relatives. The low number of pollen samples makes it difficult to be certain that $H$.

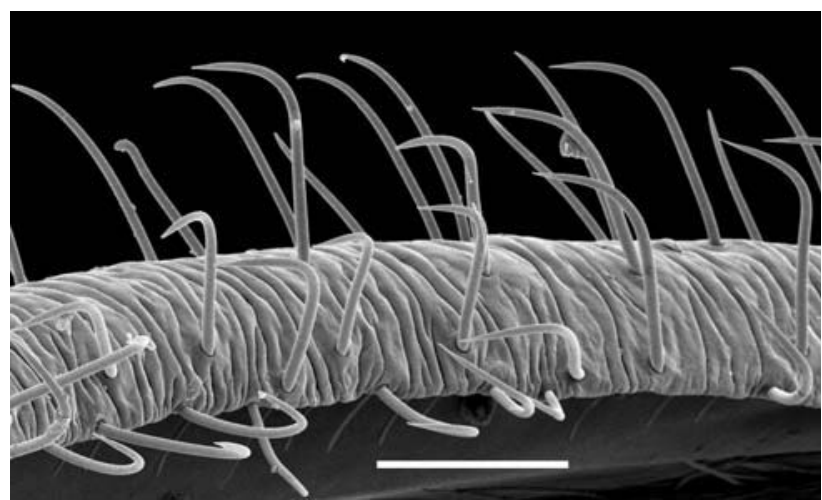

Fig. 2. Hoplitis pici: Pollen-harvesting bristles (scale bar $=$ $100 \mu \mathrm{m})$.

pici is a strict specialist of Muscari. However, as all the pollen loads analysed exclusively or predominantly contained pollen of Muscari and pollen grains of this plant genus were detected adhering to all but two females lacking pollen in their abdominal scopa, it is clear that Muscari is an important host plant of H. pici. As the pollen grains of Echium, Campanula, Lotus, Asteraceae, Brassicaceae and Lamiaceae found on the female bodies suggest, nectar may be collected from flowers other than those of Muscari. Whether H. pici uses Muscari species other than $M$. comosum is unknown, but probable as this genus is widespread in the Mediterranean area and the Near East, comprising more than 50 species, which all possess basically the same flower architecture (Hess et al., 1976).

Within the megachilid bees hooked or otherwise modified bristles on the proboscis are known to occur only in the osmiine bees. Here, they are developed either on the galeae, on the labial palpi or on both. They occur in the following species, which all use frequently or even exclusively narrow-tubed flowers of the Boraginaceae as host plants: the palaearctic Osmia (Melanosmia) pilicornis visits the flowers of Pulmonaria (Müller, 1995), three closely related nearctic Osmia (Melanosmia) species those of Hakelia, Cryptantha, Amsinckia and Lithospermum (Parker \& Tepedino, 1982), all nearctic species of Hoplitis (Proteriades) and of Hoplitis (Penteriades) those of Cryptantha (Michener, 2000) and three closely related palaearctic Haetosmia species those of Heliotropium (Peters, 1974). Other osmiine species equipped with a bristled proboscis are the nearctic Osmia (Melanosmia) mixta (Michener, 1949) and two closely related Asian species of Hoplitis (Pentadentosmia) (Popov, 1952; Peters, 1974). While no host plant record exists for O. mixta (Parker \& Tepedino, 1982), the two Pentadentosmia species were observed on small-flowered Chenopodiaceae, a group lacking tubular flowers. As already stated by Peters (1974), it is unclear whether the specialized bristles in the latter two species are indeed used to sweep pollen out of the

TABLE 1. Composition of scopal pollen contents of Hoplitis pici.

\begin{tabular}{lccc}
\hline Locality & Degree of filling of scopa & Muscari (Hyacinthaceae) & Asteraceae, Lactuceae \\
\hline GR, Pelop., Platania/Volos, 6.iv.2001 & $4 / 5$ & $100 \%$ & \\
GR, Pelop., Old Korinth, 6.iv.2000 & $2 / 5$ & $100 \%$ & $6 \%$ \\
GR, Pelop., 3 km w Old Korinth, 25.iv.1987 & $1 / 5$ & $94 \%$ & $12 \%$ \\
GR, Pelop., 3 km w Old Korinth, 25.iv.1987 & $1 / 5$ & $100 \%$ & \\
GR, Pelop., Olympia, 15.iv.1995 & $1 / 5$ & $88 \%$ & \\
GR, Rhodos, Stegna, 4.v.2005 & $1 / 5$ & $100 \%$ & \\
TK, Aydin, Bafa lake, 17.iv.1996 & $1 / 5$ & $100 \%$ & \\
\hline
\end{tabular}




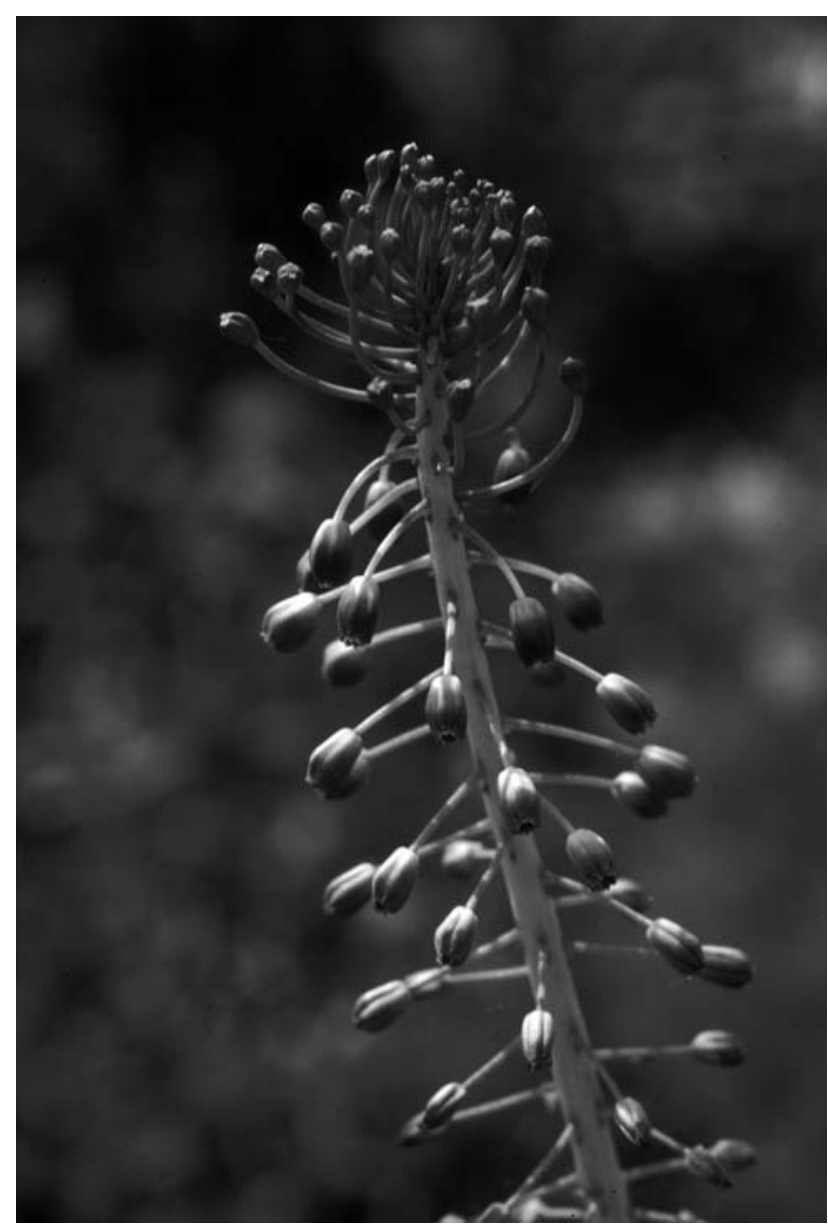

Fig. 3. Inflorescence of Muscari comosum with long-stalked, sterile flowers at the apex and more or less horizontally oriented, fertile flowers beneath.

open and flat Chenopodiaceae flowers. It is more probable that they also use narrow-tubed boraginaceous flowers in addition to Chenopodiaceae. Similarly, apart from some species of Proteriades and Penteriades, which seem to be strictly specialized on Cryptantha (Timberlake \& Michener, 1950; Hurd \& Michener, 1955; Parker, 1978), the above-mentioned osmiine bees are actually polylectic and also use pollen sources other than narrow-tubed boraginaceous flowers. In conclusion, pollencollecting devices used for extracting pollen from narrow-tubed flowers must have independently evolved at least eight times in the osmiine bees including $\mathrm{H}$. pici.

ACKNOWLEDGEMENTS. I thank W. Arens (Bad-Hersfeld), P. Hartmann (Bayreuth), M. Schwarz (Ansfelden) and K. Standfuss (Dortmund) for the loan of specimens of Hoplitis pici, U. Jauch (Institute for Botany, University of Zürich) for help with the scanning electron microscope, A. Krebs for providing the picture of Muscari comosum, K. Tschudi-Rein (ETH Zürich) for correcting the English and S. Dorn (ETH Zurich), C.D. Michener (University of Kansas) and an anonymous reviewer for helpful comments on earlier drafts of the manuscript.

\section{REFERENCES}

Ducke A. 1900: Die Bienengattung Osmia Panz. Ber. Naturw.-Med. Ver. Innsbruck 25: 1-323.

FrIESE H. 1899: Neue palaearktische Sammelbienen. Entomol. Nachr. 25: 321-346.
Hess H.E., Landolt E. \& Hirzel R. 1976: Flora der Schweiz. Vol. 1. Birkhäuser, Basel, 858 pp.

HuRd P.D. \& Michener C.D. 1955: The megachiline bees of California. Bull. Calif. Insect Survey 3: 1-248.

Le Goff G. 2003: Note sur la nidification d'Hoplitis (Hoplitis) fertoni Pérez dans la province d'Alicante (Espagne) (Hymenoptera; Apoidea; Megachilidae; Osmiini). Cette abeille est un nouvel hôte pour Chrysis hybrida Lepeletier (Hymenoptera; Chrysidoidea; Chrysididae; Chrysidini). Entomologiste 59: 97-102.

Le Goff G. 2004: Hoplitis (Hoplitis) manicata Morice, espèce nouvelle pour la faune de France et la peu commune Megachile (Pseudomegachile) ericetorum melaleuca Van der Zanden en Corse (Apoidea; Megachilidae; Megachilinae; Osmiini; Megachilini). Entomologiste 60: 9-12.

Michener C.D. 1949: Records and descriptions of American megachilid bees (Hymenoptera). J. Kansas Entomol. Soc. 22: 41-59.

Michener C.D. 2000: The Bees of the World. Johns Hopkins, Baltimore and London, $913 \mathrm{pp}$.

Morice F.D. 1901: Illustrations of the 6th of ventral segment in 17 Osmia-species of the adunca-group, with a note on the synonymy of four species, and descriptions of four which seem new. Trans. Entomol. Soc. London 1901: 161-178.

MÜLLER A. 1995: Morphological specializations in Central European bees for the uptake of pollen from flowers with anthers hidden in narrow corolla tubes (Hymenoptera: Apoidea). Entomol. Gener. 20: 43-57.

MÜLleR A. \& BANSAC N. 2004: A specialized pollen-harvesting device in western palaearctic bees of the genus Megachile (Hymenoptera, Apoidea, Megachilidae). Apidologie 35: 329-337.

Müller A. \& KuHLmann M. 2003: Narrow flower specialization in two European bee species of the genus Colletes (Hymenoptera: Apoidea: Colletidae). Eur. J. Entomol. 100: 631-635.

NEFF J.L. 2004: Hooked hairs and not so narrow tubes: two new species of Colletes Latreille from Texas (Hymenoptera: Apoidea: Colletidae). J. Hymenoptera Res. 13: 250-261.

NefF J.L. \& Simpson B.B. 1985: Hooked setae and narrow tubes: foretarsal pollen collection by Trimeria buyssoni (Hymenoptera: Masaridae). J. Kansas Entomol. Soc. 58: 730-732.

PARKer F.D. 1978: Biology of the bee genus Proteriades Titus (Hymenoptera: Megachilidae). J. Kansas Entomol. Soc. 51: 145-173.

PARKer F.D. \& TePedino V.J. 1982: A nest and pollen collection records of Osmia sculleni Sandhouse, a bee with hooked hairs on the mouthparts (Hymenoptera: Megachilidae). J. Kansas Entomol. Soc. 55: 329-334.

Peters D.S. 1974: Über die Untergattung Haetosmia Popov 1952 (Insecta: Hymenoptera: Megachilidae: Osmia). Senck. Biol. 55: 293-309.

Popov V.V. 1952: O sopryazhennykh vidakh Tridentosmia Schmied. (Hymenoptera, Megachilidae) - opilitelakh marevykh. [On related species of Tridentosmia Schmied. (Hymenoptera, Megachilidae), pollinators of the Chenopodiaceae.] Zool. Zh. 31: 183-190 [in Russian].

THORP R.W. 1979: Structural, behavioral, and physiological adaptations of bees (Apoidea) for collecting pollen. Ann. Miss. Bot. Garden 66: 788-812.

THORp R.W. 2000: The collection of pollen by bees. Plant Syst. Evol. 222: 211-223.

Timberlake P.H. \& Michener C.D. 1950: The bees of the genus Proteriades. Univ. Kansas Sci. Bull. 33: 387-440.

Westrich P. 1989: Die Bienen Baden-Württembergs. Vol. 1-2. Ulmer, Stuttgart, $972 \mathrm{pp}$ 
Westrich P. \& Schmidt K. 1986: Methoden und Anwendungsgebiete der Pollenanalyse bei Wildbienen (Hymenoptera Apoidea). Linz. Biol. Beitr. 18: 341-360.

ZANDEN G. VAN DER 1987: Neue paläarktische Taxa der Familie Megachilidae (Insecta, Hymenoptera, Apoidea). Reichenbachia 25: 73-83.
ZANDEN G. VAN DER 1988: Beitrag zur Systematik und Nomenklatur der paläarktischen Osmiini, mit Angaben über ihre Verbreitung. Zool. Med. 62: 113-133.

Received August 25, 2005; revised and accepted November 2, 2005 